\title{
60 YEARS OF NEUROENDOCRINOLOGY Regulation of mammalian neuroendocrine physiology and rhythms by melatonin
}

\author{
Jonathan D Johnston and Debra J Skene \\ Faculty of Health and Medical Sciences, University of Surrey, Guildford, Surrey GU2 7XH, UK
}

Correspondence

should be addressed

to J D Johnston

Email

j.johnston@surrey.ac.uk

\begin{abstract}
The isolation of melatonin was first reported in 1958. Since the demonstration that pineal melatonin synthesis reflects both daily and seasonal time, melatonin has become a key element of chronobiology research. In mammals, pineal melatonin is essential for transducing day-length information into seasonal physiological responses. Due to its lipophilic nature, melatonin is able to cross the placenta and is believed to regulate multiple aspects of perinatal physiology. The endogenous daily melatonin rhythm is also likely to play a role in the maintenance of synchrony between circadian clocks throughout the adult body. Pharmacological doses of melatonin are effective in resetting circadian rhythms if taken at an appropriate time of day, and can acutely regulate factors such as body temperature and alertness, especially when taken during the day. Despite the extensive literature on melatonin physiology, some key questions remain unanswered. In particular, the amplitude of melatonin rhythms has been recently associated with diseases such as type 2 diabetes mellitus but understanding of the physiological significance of melatonin rhythm amplitude remains poorly understood.
\end{abstract}

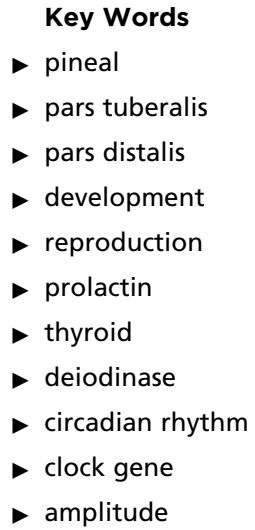

Journal of Endocrinology (2015) 226, T187-T198

\section{Melatonin and the photoneuroendocrine system}

\section{Overview of melatonin's discovery}

The discovery of melatonin was made by Lerner et al. (1958), coincidently only a few years after publication of Harris' monograph, Neural Control of the Pituitary Gland (Harris 1955), which is often considered to have established neuroendocrinology as a discipline and is celebrated in this special issue of the journal. Lerner was seeking to identify the molecule(s) in bovine pineal glands known to cause blanching of amphibian skin. This work led to isolation of a factor, termed melatonin, which causes potent aggregation of melanin granules in frog melanocytes (Lerner et al. 1958). Shortly afterwards, the chemical structure of melatonin was revealed as N-acetyl5-methoxytryptamine (Lerner et al. 1959). From its origins in a dermatology laboratory, melatonin has become a key molecule in the field of chronobiology. As described in this review, melatonin provides an extremely robust endocrine signal of both circadian time and day-length, enabling it to influence both daily and seasonal rhythms in many species. Melatonin is synthesised by multiple tissues in the body, but the pineal gland is the major

This paper is part of a thematic review section on 60 years of neuroendocrinology. The Guest Editors for this section were Ashley Grossman and Clive Coen. 
contributor to circulating melatonin concentration, as pinealectomy abolishes detectable melatonin in the blood (Lewy et al. 1980a).

\section{Circadian rhythmicity of pineal melatonin synthesis}

Concentrations of melatonin in the blood exhibit a pronounced circadian rhythm, with elevated levels during the biological night in all species. The primary driver of melatonin rhythmicity is the endogenous circadian system, as daily rhythms of melatonin persist in constant dim light and in the absence of rhythmic environmental cues. In most mammalian species, the circadian rhythm of pineal melatonin synthesis is due to a poly-synaptic pathway linking the pineal gland to the hypothalamic suprachiasmatic nuclei $(\mathrm{SCN})$, which house the master circadian clock in mammals (Moore \& Eichler 1972, Stephan \& Zucker 1972). The pathway has been mapped by classical lesioning and tracer studies (reviewed in Moore (1996)), together with transneuronal retrograde tracer experiments (Larsen et al. 1998, TeclemariamMesbah et al. 1999). From the SCN, it passes via the paraventricular nuclei, the upper thoracic intermediolateral cell column of the spinal cord and then sympathetic neurones of the superior cervical ganglion, which innervate the pineal. This series of connections linking retina to SCN to pineal gland is sometimes referred to as a photoneuroendocrine system.

The circadian, SCN-driven sympathetic innervation of the pineal gland results in activation of arylalkylamine-Nacetyltransferase (AA-NAT), a key enzyme in the melatonin synthesis pathway (Klein 2007). Noradrenaline released by the sympathetic neurones stimulates cAMP production and AA-NAT activity in pinealocytes via both $\beta 1$ (Deguchi $\&$ Axelrod 1972, Klein \& Weller 1973) and $\alpha 1$ (Klein et al. 1983, Vanecek et al. 1985) adrenoreceptors. In rodents, this leads to high amplitude rhythms in pineal Aa-nat mRNA abundance (Borjigin et al. 1995, Coon et al. 1995) indicating that AA-NAT synthesis is a major mechanism driving the melatonin synthesis rhythm. However melatonin synthesis in all species also involves important post-translational mechanisms such as the stabilisation of AA-NAT protein by interaction with 14-3-3 proteins (Ganguly et al. 2001). In comparison to rodents, pineal physiology of ungulate and primate species is believed to primarily utilise post-transcriptional mechanisms, as it exhibits very little daily change in mRNA of Aa-nat and other genes known to be rhythmic in the rodent pineal (Coon et al. 1995, Privat et al. 1999, Johnston et al. 2004). Moreover stimulation of bovine pinealocytes with noradrenaline induces AA-NAT activity without any change in Aa-nat mRNA expression (Schomerus et al. 2000). Further data describing species differences in melatonin synthesis are reviewed elsewhere (Stehle et al. 2001).

In addition to being an SCN-driven rhythm, the daily variation in melatonin synthesis is also in part regulated by the ambient light-dark cycle. Light is a powerful synchroniser of SCN rhythms (reviewed in Hughes et al. (2015)). Furthermore, exposure to light during the night acutely inhibits melatonin synthesis and secretion in both animal models (Klein \& Weller 1972, Illnerova et al. 1979) and humans (Lewy et al. 1980b). The daily rhythm of melatonin concentration is thus the result of complex interplay between endogenous and exogenous factors.

\section{Melatonin as a marker of circadian phase}

The timing of the endogenous melatonin rhythm is considered the most reliable marker of SCN clock timing and is used routinely to assess circadian phase in humans. Melatonin can be measured directly in plasma and saliva samples, or indirectly as its urinary metabolite, 6-sulphatoxymelatonin (aMT6s), thus providing circadian phase information in both laboratory and non-laboratory studies (reviewed in Skene \& Arendt (2006)). Compared with core body temperature and cortisol rhythms, melatonin is least affected by activity, sleep, meals and stress.

The timing of the rhythm can be measured by estimating the time of melatonin onset, peak or offset (reviewed in Skene \& Arendt (2006)). The time of melatonin onset in dim light conditions, the so-called dim light melatonin onset (DLMO; Lewy \& Sack 1989), has frequently been used as a marker of circadian phase, although it may be better to measure both melatonin onset and offset as there is some evidence to suggest that these may be shifted differentially (Warman et al. 2003). Preferably, however, the whole melatonin profile should be measured to capture both melatonin timing and amplitude. The timing of the melatonin and urinary aMT6s rhythms has provided important information of an individual's circadian phase in numerous studies of circadian desynchrony and has also been used to optimize the timing of light and melatonin in the treatment of circadian rhythm sleep-wake disorders.

\section{Melatonin as an endocrine calendar}

The 24-h melatonin signal not only represents endogenous circadian time but also encodes seasonal information.

Published by Bioscientifica Ltd 
Specifically, the duration of elevated melatonin concentration is proportional to duration of the night and thus dependent upon the prevailing photoperiod (reviewed in Reiter (1993)). This photoperiodic regulation of melatonin signal duration is a consequence of adaptation of SCN physiology. Day-length is encoded in multiple SCN rhythms, including gene expression, electrical activity and gating of sensitivity to input stimuli as reviewed elsewhere (Johnston 2005, Coomans et al. 2015). Altered neuronal output from the SCN then drives melatonin signal duration via the SCN-pineal poly-synaptic pathway as described above.

The ability of melatonin to provide an endocrine representation of photoperiod is an essential component of the seasonal biology of many species. Removal of the pineal gland has long been known to block the ability of photoperiod to regulate the seasonal physiology of mammals. However there was debate in the literature as to what element(s) of the melatonin signal actually carried photoperiodic information. Early studies of intact hamsters revealed an ability of melatonin injections to induce short photoperiod-like physiology, but only when given at certain times of the day (Tamarkin et al. 1976, 1977). Possible explanations for these data included rhythmic sensitivity to melatonin and extension of the endogenous melatonin signal duration by the injections. A series of elegant timed infusion studies conducted by multiple laboratories using pinealectomised animals later revealed that duration is likely to be the key feature of the melatonin rhythm that regulates photoperiodic changes in physiology (reviewed in Bartness et al. (1993)). The contrast between short duration signals in the summer and long duration winter signals is both necessary and sufficient to drive subsequent seasonal rhythms in diverse processes such as reproduction, pelage, metabolism, and immune function (Goldman 2001, Stevenson \& Prendergast 2015).

\section{Melatonin receptors}

Endogenous melatonin acts through activation of membrane bound, high affinity, G-protein coupled receptors. Early studies using the radioligand 2-[ ${ }^{125}$ I] iodomelatonin identified and quantified high-affinity melatonin receptors in numerous vertebrate species (Dubocovich 1995, Reppert \& Weaver 1995, Vanecek 1988a). Subsequent molecular cloning identified two melatonin receptors, Mel1a (MT1) and Mel1b (MT2) in mammals (Reppert et al. 1994, 1995a) and an additional melatonin receptor, Mel1c, in birds (Reppert et al. 1995b). The MT2 receptor was cloned from humans (362 amino acids) and is $60 \%$ identical to the human MT1 receptor at the amino acid level (350 amino acids). The MT2 receptor is preferentially expressed in the human retina and selected brain regions, notably the hippocampus. The expressed recombinant MT2 receptor exhibits similar ligand binding characteristics and pharmacology to the MT1 receptor (Kd $<200 \mathrm{pM}$; specificity 2-iodomelatonin $>$ melatonin $\geq 6$-chloromelatonin $>\mathrm{N}$-acetylserotonin $>>$ serotonin) and is also coupled to $G_{i}$ resulting in inhibition of adenylate cyclase, cAMP concentration and downstream signal transduction pathways (Reppert 1997).

There is a high density of melatonin receptor expression in neuroendocrine tissues, including the hypothalamic SCN, pituitary pars tuberalis (PT) and developing gonadotroph cells. Melatonin receptors have also been detected elsewhere, including the adrenal gland (MT1), arteries and heart (MT1, MT2), lung (MT1, MT2), liver (MT1, MT2), kidney (MT1), small intestine (MT2), skin (MT1, MT2), and in T and B lymphocytes (MT1) (reviewed in Zawilska et al. (2009)). However the physiological function of melatonin is not well understood in many of these tissues. Notable examples of melatonin's regulation of endocrine function include regulation of metabolic physiology, such as insulin secretion and glucose homeostasis (Peschke 2008, Karamitri et al. 2013). This review, however, will focus on neuroendocrine examples, primarily via its action in the hypothalamus and pituitary gland.

\section{Circadian actions of endogenous melatonin in adults}

The MT1 receptor is strongly expressed in the SCN, which is considered a major site of melatonin action. Early studies using mice with targeted disruption of the Mel1a (MT1) receptor revealed that this receptor was necessary for the acute inhibitory action of melatonin on SCN neuronal firing (Liu et al. 1997). However, phase shifts by melatonin were still evident in these MT1 deficient mice (Liu et al. 1997). Subsequent transgenic studies (von Gall et al. 2002b, Jin et al. 2003) and pharmacological studies showing blockade of melatonin-induced phase shifts by MT2 antagonists (Dubocovich et al. 1998, Hunt et al. 2001) suggest MT2 receptor involvement in melatonin's phase shifting action.

In addition to its effects in the SCN, melatonin's robust rhythmicity in the circulation makes it an attractive candidate molecule involved in the synchronisation of circadian clocks throughout the body. This issue

Published by Bioscientifica Ltd 
has been discussed in detail by others (Stehle et al. 2003, Pevet et al. 2006).

\section{Regulation of seasonal physiology via the pituitary pars tuberalis (PT)}

Aside from the SCN, the pituitary gland is the best studied melatonin target tissue. In adult mammals, the dominant pituitary site of melatonin action is the PT, a thin layer of the anterior pituitary that surrounds the pituitary stalk and extends rostrally along the ventral surface of the median eminence (reviewed in Wittkowski et al. (1999)). Co-localisation studies have revealed expression of MT1 receptors in thyroid stimulating hormone (TSH)-positive cells of the PT (Klosen et al. 2002, Dardente et al. 2003a). These cells are often referred to as PT-specific thyrotrophs. Despite their expression of TSH, they lack cellular components associated with the primary population of thyrotroph cells in the pars distalis of the anterior pituitary (Bockmann et al. 1997). It is now believed that melatonin signal duration drives the photoperiodic control over multiple aspects of neuroendocrine physiology, including the lactotrophic and reproductive axes, via the PT in adult mammals.

\section{Photoperiodic regulation of prolactin secretion}

In many seasonally breeding species, the lactotrophic axis exhibits robust annual cycles with increased prolactin secretion during the spring and summer months, irrespective of the timing of the breeding season. Compelling in vivo evidence for an intra-pituitary mechanism regulating photoperiodic prolactin rhythm came from the hypothalamo-pituitary disconnected (HPD) ram model. The HPD ram lacks neuronal connections between the hypothalamus and pituitary gland, but has intact pituitary vasculature (Clarke et al. 1983). Despite this lack of neuronal connection between hypothalamus and pituitary, alternate summer and winter photoperiods are able to drive appropriate annual cycles of plasma prolactin concentration (Lincoln \& Clarke 1994).

Studies of pituitary melatonin receptor expression revealed a lack of melatonin receptors on lactotroph cells, implying an indirect mechanism of melatonin on prolactin secretion. The importance of the PT in the seasonal regulation of prolactin secretion was first demonstrated by the fact that PT-conditioned medium stimulates prolactin secretion from pituitary pars distalis cell cultures (Hazlerigg et al. 1996, Morgan et al. 1996). It was therefore postulated that the photoperiodic melatonin signal regulates the release of a prolactin secretagogue, termed tuberalin, from the PT. Later evidence indicated that tuberalin secretion is dependent upon photoperiod (Stirland et al. 2001) and endogenous seasonal timing mechanisms (Johnston et al. 2003a, Lincoln et al. 2005). Despite strong evidence for the existence of tuberalin, attempts to identify it have not been successful (Lafarque et al. 1998, Guerra \& Rodriguez 2001, Graham et al. 2002). More detailed reviews of this subject can be found elsewhere (Johnston 2004, Dardente 2007, Dupre 2011).

\section{Photoperiodic regulation of reproduction}

More recently, the PT has also been implicated in melatonin-driven seasonal reproductive rhythms. Based upon the results from the HPD ram (Lincoln \& Clarke 1994) and lesioning studies in seasonally breeding hamsters (Maywood \& Hastings 1995), 'a dual site hypothesis' was originally proposed, in which melatonin acted at the PT to regulate seasonal prolactin rhythms, but in the hypothalamus to regulate seasonal reproduction. Despite this supportive evidence, there were also data in conflict with the dual-site hypothesis. For example, some seasonally breeding species had no detectable melatonin receptors within the hypothalamus (Weaver $\&$ Reppert 1990).

Data have linked thyroid hormone physiology to seasonality in birds for many years (reviewed in Follett \& Nicholls (1984)). A more recent breakthrough in the understanding of seasonal physiology also came from studies of birds, specifically the Japanese quail. This research revealed that photoperiod regulates expression of deiodinase (DIO) enzymes within the hypothalamus to drive seasonal variation in local concentration of tri-iodothyronine $\left(\mathrm{T}_{3}\right)$, the most active form of thyroid hormone (Yoshimura et al. 2003, Yasuo et al. 2005). This model has now been extended to mammals, in which it had been previously demonstrated that thyroid hormone signalling is involved in seasonal rhythms (Vriend 1985, Nicholls et al. 1988, Moenter et al. 1991, Webster et al. 1991). In brief, melatonin action on the PT-specific thyrotroph cells is proposed to regulate release of TSH, which then functions via a retrograde signalling pathway to regulate DIO expression in hypothalamic tanycytes that line the third ventricle (Hanon et al. 2008). Increased expression of DIO2 and/or reduced DIO3 in the lengthening photoperiods of spring and summer then increases conversion of thyroxine to $T_{3}$. The mechanism to produce locally elevated $T_{3}$ concentrations in long photoperiods

Published by Bioscientifica Ltd 
appears to be the same in both long and short-photoperiod breeders (Revel et al. 2006, Hanon et al. 2008). This therefore suggests that species-specific mechanisms within the hypothalamus regulate seasonal breeding status downstream of $\mathrm{T}_{3}$ generation. For further detail, readers are referred to recent reviews of this topic (Yoshimura 2013, Dardente et al. 2014, Wood \& Loudon 2014).

\section{Decoding the durational melatonin signal}

Despite recent advances in determining the endocrine mechanisms through which melatonin drives seasonal physiology, the cell signalling mechanisms used to interpret melatonin signal duration are still unclear. To date, evidence suggests that melatonin duration is able to alter sensitisation of intracellular signal transduction pathways and also determine the temporal coincidence of rhythmic gene expression.

Chronic activation of receptors that are negatively coupled to adenylate cyclase (AC) can lead to sensitisation of AC signal transduction pathways (Thomas \& Hoffman 1987). Indeed, pre-treatment of Chinese hamster ovary cells expressing human MT1 (Witt-Enderby et al. 1998), neonatal rat pituitary cells (Pelisek \& Vanecek 2000) and pancreatic INS-1 $\beta$ cells (Kemp et al. 2002) with melatonin sensitises subsequent stimulation by forskolin. However it is the PT cell model that has been most used to study sensitisation effects of melatonin, as reviewed in detail by Barrett et al. (2003). In the context of understanding the decoding of photoperiodic melatonin signalling, it is not sufficient to identify the presence of sensitisation per se in PT cells, but determine whether there are differences in sensitisation between melatonin signal durations encountered in long and short photoperiods. This experiment was performed in ovine pituitary cells that, in many temperate latitudes, would be exposed to melatonin signal duration of $\sim 8 \mathrm{~h}$ in a long summer photoperiod and $16 \mathrm{~h}$ in a short winter photoperiod. Exposure of ovine PT cells to $16 \mathrm{~h}$ of melatonin increases AC sensitivity to stimulants such as forskolin (Hazlerigg et al. 1993) and CTX (Barrett et al. 2000), in addition to causing a significant increase in basal AC activity (Hazlerigg et al. 1993). By contrast, exposure to a melatonin signal of 8-h or less causes less sensitisation (Hazlerigg et al. 1993). Altered sensitisation of PT cells by physiologically encountered melatonin signals may therefore contribute to photoperiodic timing mechanisms.

Identification of clock gene expression in the PT (Sun et al. 1997) invited speculation that there may be circadian mechanisms within the PT involved in decoding melatonin signals. Initial studies focused on Period1 (Per1), which is known to be sensitive to cAMP-dependent signalling, and revealed a transient increase of expression immediately following the morning decline of melatonin (Morgan et al. 1998, von Gall et al. 2002a). Later work revealed rhythmic expression of mRNA for multiple clocks genes in the ovine PT (Lincoln et al. 2002). Of note Cryptochrome1 (Cry1) and Per1 mRNAs were found to be expressed immediately following the onset and offset of the daily melatonin signal, respectively, in both long and short photoperiod (Lincoln et al. 2002). As formation of PER and CRY protein complexes is an important functional step in circadian transcriptional repression, it has been hypothesised that melatonin signal duration may transmit day length information via the differential formation of such protein complexes (Lincoln et al. 2003). The demonstration that melatonin onset per se induces PT expression of Cry1 (Dardente et al. 2003b, Hazlerigg et al. 2004), made it one of the first genes reported to be acutely stimulated by melatonin. However, subsequent work revealed that melatonin onset stimulates a range of genes and transcription factor pathways (Dupre et al. 2008, Fustin et al. 2009, Unfried et al. 2010), indicating that a molecular coincidence model need not necessarily be dependent upon clock genes, but could conceivably include acute regulation of multiple genes and their protein products. Direct testing of the coincidence model has not yet been possible to a large degree due to the technical difficulty associated with in vivo genetic manipulation in photoperiodic species.

\section{Melatonin signalling in neuroendocrine tissues during early development}

Although the PT has proved to be a valuable model tissue for the study of melatonin action in adult animals, progress has been made understanding the physiological actions of melatonin elsewhere in the body at various developmental stages. Melatonin became a focus of research on maternal-foetal signalling, due to its robust circadian rhythm and its lipophilic nature, which allows it to cross the placenta (Reppert et al. 1979, Yellon \& Longo 1987, Zemdegs et al. 1988) and even pass into milk (Reppert \& Klein 1978, Illnerova et al. 1993). In addition to the following examples, evidence indicates effects of maternal melatonin on foetal and neonatal endocrine physiology outside of the scope of this review, including the regulation of adrenal gland (Torres-Farfan et al. 2011) and adipose tissue (Seron-Ferre et al. 2014) function.

Published by Bioscientifica Ltd 


\section{Direct regulation of the pituitary pars distalis}

The distribution of melatonin receptors is more widespread during embryogenesis than in adulthood, suggesting novel role(s) for melatonin in early development (Davis 1997, Seron-Ferre et al. 2012). Although developmental changes in melatonin receptor expression have been reported in neuroendocrine tissues such as the thyroid and nasal epithelium (Rivkees \& Reppert 1991, Helliwell \& Williams 1994), the pituitary gland is the best studied example.

Initial research in this area demonstrated that melatonin is able to acutely inhibit gonadotrophin-releasing hormone $(\mathrm{GnRH})$-stimulated gonadotrophin secretion from neonatal rat pituitary cells (Martin \& Klein 1976). Developmental loss of melatonin sensitivity in the rat pituitary was then revealed by the gradual decline of this endocrine function over the first 2-3 weeks of postnatal life (Martin \& Sattler 1979), together with a parallel postnatal loss of iodo-melatonin binding sites (Vanecek 1988b). These developmental changes and the mechanisms of melatonin signalling in gonadotroph cells are reviewed in detail elsewhere (Vanecek 1999).

Mapping of Mt1 mRNA expression using in situ hybridisation histochemistry has allowed more detailed analysis of melatonin sensitivity in the developing rat pituitary. Consistent with iodo-melatonin binding studies, the onset of Mt1 expression is at embryonic day 15 (Johnston et al. 2006). During embryogenesis, Mt1 is strongly expressed in the PT (or rostral tip) region of the anterior pituitary and extends along the ventral pituitary surface, a region known to house newly differentiated gonadotroph cells (Scully \& Rosenfeld 2002). Direct evidence of melatonin receptor expression in gonadotroph cells was then provided by co-localisation of Mt1 with luteinising hormone beta (LH $\beta$ ) and alpha glycoprotein subunit ( $\alpha$ GSU) mRNA in both the embryonic and neonatal rat pituitary (Johnston et al. 2003b, Johnston et al. 2006). The effects of melatonin on reproductive physiology in early development are therefore likely to be, at least in part, via a direct action on the pituitary gonadotroph cells, in contrast to the mechanisms driving photoperiodic reproduction in adults, as previously described.

Investigation of the molecular mechanisms regulating Mt1 promoter activity has attempted to identify the mechanisms that drive down-regulation of melatonin receptor expression in developing pituitary gonadotroph cells. Sequencing of the rat Mt1 promoter (Johnston et al. 2003c) and subsequent reporter assays (Johnston et al.
$2003 b$ ) suggested the presence of a functional cis-element for the transcription factor EGR-1 proximal to the Mt1 transcription start site. Expression of EGR-1 in gonadotroph cells is induced by GnRH and is a molecular component through which GnRH stimulates LH $\beta$ synthesis (Dorn et al. 1999, Tremblay \& Drouin 1999). It was therefore hypothesised that, around late embryogenesis in rodents, the onset of pulsatile GnRH secretion from the hypothalamus induces EGR-1 expression to simultaneously stimulate $L h \beta$ and inhibit $M t 1$ transcription. The hypothesis received support from analysis of the hypogonadal mouse, which is unable to synthesise GnRH and exhibits a fourfold increase in pituitary Mt1 mRNA compared to wild type littermates (Johnston et al. $2003 b$ ). Further support came from in vitro experiments, which have shown that endogenous Mt1 mRNA expression is up-regulated by a GnRH receptor antagonist in GT1-7 neuronal cells (Ishii et al. 2009) and downregulated by a GnRH receptor agonist in the $\alpha \mathrm{T}_{3}-1$ gonadotroph cell line (Bae et al. 2014). However, recent data have also revealed that pituitary Mt1 expression is unaltered in adult rats treated with a GnRH receptor antagonist and also in Egr1 ${ }^{-/-}$mice (Bae et al. 2014). It is therefore clear that further work is required to fully elucidate the mechanisms controlling melatonin sensitivity in developing gonadotroph cells.

\section{Synchronisation of foetal circadian rhythms by maternal melatonin}

Circadian clocks have been widely reported in foetal and neonatal individuals of model species (reviewed in Seron-Ferre et al. (2012)). Moreover, these clocks are synchronised (entrained) by maternal factors, during the early stages of development before the SCN receive neuronal innervation from the retina (Stanfield \& Cowan 1976, Mason et al. 1977).

Much of the evidence for maternal melatonin in perinatal circadian entrainment has derived from studies of the Syrian hamster, which possesses more melatonin receptors in the SCN of foetal and neonate animals than adults (Duncan \& Davis 1993, Gauer et al. 1998). Whereas behavioural rhythms of adult hamsters appear insensitive to melatonin (Hastings et al. 1992), neonate hamsters are readily entrained to melatonin injections (Grosse et al. 1996). Remarkably, injection of pregnant mothers entrains rhythms of foetal pups, demonstrating the effect of melatonin and its ability to cross the placenta (Davis \& Mannion 1988). Evidence for the role of SCN melatonin receptors in this process comes from elegant

Published by Bioscientifica Ltd 
transplantation studies. Lesioning of the SCN in adult hamsters renders them arrhythmic, but transplantation of foetal SCN tissue restores behavioural rhythms that can be entrained by melatonin (Grosse \& Davis 1998).

\section{Pharmacological uses of melatonin}

\section{Chronobiotic effects}

The ability of exogenously administered melatonin to phase shift human circadian rhythms was described in the 1980s (Arendt et al. 1985). If given (0.5-10 mg p.o.) before the natural rise of endogenous melatonin, phase advances in sleep, core body temperature, melatonin and prolactin have been observed (Deacon \& Arendt 1995, Krauchi et al. 1997, Rajaratnam et al. 2003). By contrast, melatonin administered in the early biological morning (i.e. 1-4 $\mathrm{h}$ after the core body temperature nadir) can produce phase delays in circadian timing. This ability of melatonin to advance or delay clock timing depending on the biological time of administration has been described in terms of a phase response curve (PRC) (Lewy et al. 1992, Middleton et al. 1997, Revell \& Eastman 2005, Burgess et al. 2008). The magnitude of the phase shift is dose-dependent (Deacon \& Arendt 1995, Burgess et al. 2010).

The phase shifting effects of melatonin have been utilised in the treatment of circadian rhythm sleep-wake disorders in which the sleep/wake cycle is desynchronised from the circadian timing system, reviewed in Arendt \& Skene (2005). Appropriately timed melatonin has been shown to alleviate symptoms of jet lag and night shift work. Melatonin is also the treatment of choice for non24-h sleep-wake disorder suffered by totally blind people with no conscious light perception (Skene \& Arendt 2007). In this condition, melatonin entrains the free-running non-24-h circadian rhythms including the sleep-wake cycle leading to increased night sleep duration and a reduction in the number and duration of daytime naps. Melatonin (0.3-5 mg p.o) has also been used in the treatment of delayed sleep-wake phase disorder (DPSD), with dosing in the early biological evening (5-6.5 h before DLMO) proving most effective (Nagtegaal et al. 1998, Mundey et al. 2005), presumably since this maximises melatonin's phase advancing effect according to the published melatonin PRCs.

A great deal of effort has focused on trying to optimise melatonin's phase shifting effect by investigating the best time of administration (biological time and clock time), the lowest effective dose, the optimal treatment regimen (duration), frequency of dosing (set or staggered) and type of formulation (fast or slow release) (reviewed in Arendt et al. (2008)). More research is still needed so that these parameters are optimised for each circadian rhythm sleepwake disorder.

\section{Acute pharmacological effects}

Exogenous melatonin causes an immediate drop in core body temperature, reduced alertness and increased tiredness (Deacon et al. 1994). Studies suggest that these acute effects are more pronounced if melatonin is given during the day when endogenous melatonin production is low/undetectable (Dollins et al. 1994). Transient sleepiness produced following melatonin ingestion before bedtime most likely accounts for the reduced sleep latency reported in several studies (Zhdanova et al. 1996, Lemoine et al. 2007). The effect of melatonin on polysomnographic sleep is less consistent with studies showing conflicting results (reviewed in Turek \& Gillette (2004)).

\section{Melatonin agonists}

The similarity in pharmacology between the MT1 and MT2 receptors has hampered the identification of selective agonists to MT1 or MT2. Current melatonin agonists being developed have high affinity at both the MT1 and MT2 receptors, e.g. agomelatine (S20098, Servier), ramelteon (TAK-375, Takeda), LY156735 (Eli Lilly), tasimelteon (VEC-162, Bristol-Myers Squibb Co, licensed to Vanda). For reviews of these melatonin agonists the reader is referred to (Turek \& Gillette 2004, Zawilska et al. 2009). These melatonin agonists are in various stages of development and drug registration. Unfortunately it is unclear how the efficacy of these novel agonists compare directly with melatonin in clinical trials since head to head comparison with melatonin is not a prerequisite for drug registration.

\section{Perspective/future areas of research}

This review has primarily dealt with the generation and function of physiological rhythms of pineal melatonin synthesis, which results in the rhythms of melatonin in the blood. Whereas the timing of the endogenous melatonin rhythm has been a major focus of the published literature, what determines the amplitude of the melatonin rhythm is less well studied. Melatonin amplitude, whilst consistent within an individual, is highly variable between individuals, declines with age and is acutely suppressed by light at night, as previously described.

Published by Bioscientifica Ltd 
Our recent research has shown reduced melatonin amplitude in type 2 diabetes mellitus compared with age and weight matched controls (Mantele et al. 2012), consistent with epidemiological data inversely associating melatonin concentration with insulin signalling (McMullan et al. 2013) and a broader literature linking melatonin signalling with glucose homeostasis (Peschke 2008, Karamitri et al. 2013). In this and other scenarios, understanding the physiological relevance of melatonin rhythm amplitude therefore warrants further investigation and may provide novel insights into the physiological roles of melatonin.

One powerful novel tool to understand the mechanisms underlying links between melatonin, circadian rhythms, sleep and metabolism is metabolic profiling, or metabolomics. We are currently using liquid chromatography mass spectrometry to characterise $24-\mathrm{h}$ metabolite rhythms and the effect of sleep and sleep deprivation on the human metabolome (Ang et al. 2012, Davies et al. 2014). This will help to better understand melatonin, circadian timing, sleep-wake regulation and associated physiological pathways.

\section{Declaration of interest}

The authors declare that there is no conflict of interest that could be perceived as prejudicing the impartiality of this review.

\section{Funding}

The authors' recent work related to the topic of this review was supported by the Biotechnology and Biological Sciences Research Council (grant numbers BB/F020309/1 and BB/I019405/1). D J S is a Royal Society Wolfson Research Merit Award holder.

\section{Acknowledgements}

The authors wish to acknowledge the long-term mentorship of many colleagues, in particular Josephine Arendt, Professor Emeritus (University of Surrey, 1977 - present). Josephine Arendt was a pioneer in the study of melatonin in human health and disease and has been instrumental in establishing chronobiology research at the University of Surrey.

\section{References}

Ang JE, Revell V, Mann A, Mantele S, Otway DT, Johnston JD, Thumser AE, Skene DJ \& Raynaud F 2012 Identification of human plasma metabolites exhibiting time-of-day variation using an untargeted liquid chromatography-mass spectrometry metabolomic approach. Chronobiology International 29 868-881. (doi:10.3109/07420528.2012.699122)

Arendt J \& Skene DJ 2005 Melatonin as a chronobiotic. Sleep Medicine Reviews 9 25-39. (doi:10.1016/j.smrv.2004.05.002)

Arendt J, Bojkowski C, Folkard S, Franey C, Marks V, Minors D, Waterhouse J, Wever RA, Wildgruber C \& Wright J 1985 Some effects of melatonin and the control of its secretion in humans. Ciba Foundation Symposium $117266-283$
Arendt J, Van Someren EJ, Appleton R, Skene DJ \& Akerstedt T 2008 Clinical update: melatonin and sleep disorders. Clinical Medicine 8 381-383. (doi:10.7861/clinmedicine.8-4-381)

Bae SE, Wright IK, Wyse C, Samson-Desvignes N, Le Blanc P, Laroche S, Hazlerigg DG \& Johnston JD 2014 Regulation of pituitary MT1 melatonin receptor expression by gonadotrophin-releasing hormone (GnRH) and early growth response factor-1 (Egr-1): in vivo and in vitro studies. PLoS ONE 9 e90056. (doi:10.1371/journal.pone.0090056)

Barrett P, Choi WS, Morris M \& Morgan P 2000 A role for tyrosine phosphorylation in the regulation and sensitization of adenylate cyclase by melatonin. FASEB Journal 14 1619-1628. (doi:10.1096/fj.14. 11.1619)

Barrett P, Schuster C, Mercer J \& Morgan PJ 2003 Sensitization: a mechanism for melatonin action in the pars tuberalis. Journal of Neuroendocrinology 15 415-421. (doi:10.1046/j.1365-2826. 2003.00988.x)

Bartness TJ, Powers JB, Hastings MH, Bittman EL \& Goldman BD 1993 The timed infusion paradigm for melatonin delivery: what has it taught us about the melatonin signal, its reception, and the photoperiodic control of seasonal responses? Journal of Pineal Research 15 161-190. (doi:10.1111/j.1600-079X.1993.tb00903.x)

Bockmann J, Bockers TM, Winter C, Wittkowski W, Winterhoff H, Deufel T \& Kreutz MR 1997 Thyrotropin expression in hypophyseal pars tuberalis-specific cells is 3,5,3'-triiodothyronine, thyrotropin-releasing hormone, and pit-1 independent. Endocrinology 138 1019-1028.

Borjigin J, Wang MM \& Snyder SH 1995 Diurnal variation in mRNA encoding serotonin N-acetyltransferase in pineal gland. Nature $\mathbf{3 7 8}$ 783-785. (doi:10.1038/378783a0)

Burgess HJ, Revell VL \& Eastman CI 2008 A three pulse phase response curve to three milligrams of melatonin in humans. Journal of Physiology 586 639-647. (doi:10.1113/jphysiol.2007.143180)

Burgess HJ, Revell VL, Molina TA \& Eastman CI 2010 Human phase response curves to three days of daily melatonin: $0.5 \mathrm{mg}$ versus $3.0 \mathrm{mg}$. Journal of Clinical Endocrinology and Metabolism 95 3325-3331. (doi:10.1210/jc.2009-2590)

Clarke IJ, Cummins JT \& de Kretser DM 1983 Pituitary gland function after disconnection from direct hypothalamic influences in the sheep. Neuroendocrinology 36 376-384. (doi:10.1159/000123484)

Coomans CP, Ramkisoensing A \& Meijer JH 2015 The suprachiasmatic nuclei as a seasonal clock. Frontiers in Neuroendocrinology 37 29-42. (doi:10.1016/j.yfrne.2014.11.002)

Coon SL, Roseboom PH, Baler R, Weller JL, Namboodiri MA, Koonin EV \& Klein DC 1995 Pineal serotonin $\mathrm{N}$-acetyltransferase: expression cloning and molecular analysis. Science 270 1681-1683. (doi:10.1126/science. 270.5242.1681)

Dardente H 2007 Does a melatonin-dependent circadian oscillator in the pars tuberalis drive prolactin seasonal rhythmicity? Journal of Neuroendocrinology 19 657-666. (doi:10.1111/j.1365-2826.2007.01564.x)

Dardente H, Klosen P, Pevet P \& Masson-Pevet M 2003a MT1 melatonin receptor mRNA expressing cells in the pars tuberalis of the European hamster: effect of photoperiod. Journal of Neuroendocrinology $\mathbf{1 5}$ 778-786. (doi:10.1046/j.1365-2826.2003.01060.x)

Dardente H, Menet JS, Poirel VJ, Streicher D, Gauer F, Vivien-Roels B, Klosen P, Pevet P \& Masson-Pevet M 2003b Melatonin induces Cry1 expression in the pars tuberalis of the rat. Brain Research. Molecular Brain Research 114 101-106. (doi:10.1016/S0169-328X(03)00134-7)

Dardente H, Hazlerigg DG \& Ebling FJ 2014 Thyroid hormone and seasonal rhythmicity. Frontiers in Endocrinology 5 19. (doi:10.3389/fendo.2014. 00019)

Davies SK, Ang JE, Revell VL, Holmes B, Mann A, Robertson FP, Cui N, Middleton B, Ackermann K, Kayser M et al. 2014 Effect of sleep deprivation on the human metabolome. PNAS 111 10761-10766. (doi:10.1073/pnas.1402663111)

Davis FC 1997 Melatonin: role in development. Journal of Biological Rhythms 12 498-508. (doi:10.1177/074873049701200603) 
Davis FC \& Mannion J 1988 Entrainment of hamster pup circadian rhythms by prenatal melatonin injections to the mother. American Journal of Physiology 255 R439-R448.

Deacon S \& Arendt J 1995 Melatonin-induced temperature suppression and its acute phase-shifting effects correlate in a dose-dependent manner in humans. Brain Research 688 77-85. (doi:10.1016/00068993(95)96872-I)

Deacon S, English J \& Arendt J 1994 Acute phase-shifting effects of melatonin associated with suppression of core body temperature in humans. Neuroscience Letters 178 32-34. (doi:10.1016/03043940(94)90282-8)

Deguchi T \& Axelrod J 1972 Control of circadian change of serotonin $\mathrm{N}$-acetyltransferase activity in the pineal organ by the $\beta$-adrenergic receptor. PNAS 69 2547-2550. (doi:10.1073/pnas.69.9.2547)

Dollins AB, Zhdanova Wurtm IV, an RJ, Lynch HJ \& Deng MH 1994 Effect of inducing nocturnal serum melatonin concentrations in daytime on sleep, mood, body temperature, and performance. PNAS 91 1824-1828. (doi:10.1073/pnas.91.5.1824)

Dorn C, Ou Q, Svaren J, Crawford PA \& Sadovsky Y 1999 Activation of luteinizing hormone $\beta$ gene by gonadotropin-releasing hormone requires the synergy of early growth response-1 and steroidogenic factor-1. Journal of Biological Chemistry 274 13870-13876. (doi:10.1074/ jbc.274.20.13870)

Dubocovich ML 1995 Melatonin receptors: are there multiple subtypes? Trends in Pharmacological Sciences 16 50-56. (doi:10.1016/S01656147(00)88978-6)

Dubocovich ML, Yun K, Al-Ghoul WM, Benloucif S \& Masana MI 1998 Selective MT2 melatonin receptor antagonists block melatoninmediated phase advances of circadian rhythms. FASEB Journal 12 1211-1220.

Duncan MJ \& Davis FC 1993 Developmental appearance and age related changes in specific 2-[125I]iodomelatonin binding sites in the suprachiasmatic nuclei of female Syrian hamsters. Brain Research. Developmental Brain Research 73 205-212. (doi:10.1016/01653806(93)90140-6)

Dupre SM 2011 Encoding and decoding photoperiod in the mammalian pars tuberalis. Neuroendocrinology 94 101-112. (doi:10.1159/ 000328971)

Dupre SM, Burt DW, Talbot R, Downing A, Mouzaki D, Waddington D, Malpaux B, Davis JR, Lincoln GA \& Loudon AS 2008 Identification of melatonin-regulated genes in the ovine pituitary pars tuberalis, a target site for seasonal hormone control. Endocrinology 149 5527-5539. (doi:10.1210/en.2008-0834)

Follett BK \& Nicholls TJ 1984 Photorefractoriness in Japanese quail: possible involvement of the thyroid gland. Journal of Experimental Zoology 232 573-580. (doi:10.1002/jez.1402320325)

Fustin JM, Dardente H, Wagner GC, Carter DA, Johnston JD, Lincoln GA \& Hazlerigg DG 2009 Egr1 involvement in evening gene regulation by melatonin. FASEB Journal 23 764-773. (doi:10.1096/fj.08-121467)

von Gall C, Garabette ML, Kell CA, Frenzel S, Dehghani F, Schumm-Draeger PM, Weaver DR, Korf HW, Hastings MH \& Stehle JH 2002a Rhythmic gene expression in pituitary depends on heterologous sensitization by the neurohormone melatonin. Nature Neuroscience 5 234-238. (doi:10. 1038/nn806)

von Gall C, Stehle JH \& Weaver DR $2002 b$ Mammalian melatonin receptors: molecular biology and signal transduction. Cell and Tissue Research 309 151-162. (doi:10.1007/s00441-002-0581-4)

Ganguly S, Gastel JA, Weller JL, Schwartz C, Jaffe H, Namboodiri MA, Coon SL, Hickman AB, Rollag M, Obsil T et al. 2001 Role of a pineal cAMPoperated arylalkylamine N-acetyltransferase/14-3-3-binding switch in melatonin synthesis. PNAS 98 8083-8088. (doi:10.1073/pnas. 141118798)

Gauer F, Schuster C, Poirel VJ, Pevet P \& Masson-Pevet M 1998 Cloning experiments and developmental expression of both melatonin receptor Mel1A mRNA and melatonin binding sites in the Syrian hamster suprachiasmatic nuclei. Brain Research. Molecular Brain Research 60 193-202. (doi:10.1016/S0169-328X(98)00177-6)

Goldman BD 2001 Mammalian photoperiodic system: formal properties and neuroendocrine mechanisms of photoperiodic time measurement. Journal of Biological Rhythms 16 283-301. (doi:10.1177/ 074873001129001980)

Graham ES, Webster CA, Hazlerigg DG \& Morgan PJ 2002 Evidence for the biosynthesis of a prolactin-releasing factor from the ovine pars tuberalis, which is distinct from thyrotropin-releasing hormone. Journal of Neuroendocrinology 14 945-954. (doi:10.1046/j.1365-2826. 2002.00848.x)

Grosse J \& Davis FC 1998 Melatonin entrains the restored circadian activity rhythms of syrian hamsters bearing fetal suprachiasmatic nucleus grafts. Journal of Neuroscience 18 8032-8037.

Grosse J, Velickovic A \& Davis FC 1996 Entrainment of Syrian hamster circadian activity rhythms by neonatal melatonin injections. American Journal of Physiology 270 R533-R540.

Guerra M \& Rodriguez EM 2001 Identification, cellular and subcellular distribution of 21 and $72 \mathrm{kDa}$ proteins (tuberalins?) secreted by specific cells of the pars tuberalis Journal of Endocrinology 168 363-379. (doi:10.1677/joe.0.1680363)

Hanon EA, Lincoln GA, Fustin JM, Dardente H, Masson-Pevet M, Morgan PJ \& Hazlerigg DG 2008 Ancestral TSH mechanism signals summer in a photoperiodic mammal. Current Biology 18 1147-1152. (doi:10.1016/j. cub.2008.06.076)

Harris GW 1955 Neural Control of the Pituitary Gland. London: Edward Arnold.

Hastings MH, Mead SM, Vindlacheruvu RR, Ebling FJ, Maywood ES \& Grosse J 1992 Non-photic phase shifting of the circadian activity rhythm of Syrian hamsters: the relative potency of arousal and melatonin. Brain Research 591 20-26. (doi:10.1016/00068993(92)90973-D)

Hazlerigg DG, Gonzalez-Brito A, Lawson W, Hastings MH \& Morgan PJ 1993 Prolonged exposure to melatonin leads to time-dependent sensitization of adenylate cyclase and down-regulates melatonin receptors in pars tuberalis cells from ovine pituitary. Endocrinology 132 285-292.

Hazlerigg DG, Hastings MH \& Morgan PJ 1996 Production of a prolactin releasing factor by the ovine pars tuberalis. Journal of Neuroendocrinology 8 489-492. (doi:10.1046/j.1365-2826.1996.04971.x)

Hazlerigg DG, Andersson H, Johnston JD \& Lincoln G 2004 Molecular characterization of the long-day response in the Soay sheep, a seasonal mammal. Current Biology 14 334-339. (doi:10.1016/j.cub.2004.01.057)

Helliwell RJ \& Williams LM 1994 The development of melatonin-binding sites in the ovine fetus. Journal of Endocrinology 142 475-484. (doi:10.1677/joe.0.1420475)

Hughes S, Jagannath A, Hankins MW, Foster RG \& Peirson SN 2015 Photic regulation of clock systems. Methods in Enzymology 552 125-143.

Hunt AE, Al-Ghoul WM, Gillette MU \& Dubocovich ML 2001 Activation of MT(2) melatonin receptors in rat suprachiasmatic nucleus phase advances the circadian clock. American Journal of Physiology. Cell Physiology 280 C110-C118.

Illnerova H, Vanecek J, Krecek J, Wetterberg L \& Saaf J 1979 Effect of one minute exposure to light at night on rat pineal serotonin Nacetyltransferase and melatonin. Journal of Neurochemistry 32 673-675. (doi:10.1111/j.1471-4159.1979.tb00407.x)

Illnerova H, Buresova M \& Presl J 1993 Melatonin rhythm in human milk. Journal of Clinical Endocrinology and Metabolism 77 838-841.

Ishii H, Sato S, Yin C, Sakuma Y \& Kato M 2009 Cetrorelix, a gonadotropinreleasing hormone antagonist, induces the expression of melatonin receptor 1a in the gonadotropin-releasing hormone neuronal cell line GT1-7. Neuroendocrinology 90 251-259. (doi:10.1159/000231993)

Jin X, von Gall C, Pieschl RL, Gribkoff VK, Stehle JH, Reppert SM \& Weaver DR 2003 Targeted disruption of the mouse Mel(1b) melatonin receptor. Molecular and Cellular Biology 23 1054-1060. (doi:10.1128/ MCB.23.3.1054-1060.2003) http://joe.endocrinology-journals.org

DOI: 10.1530/JOE-15-0119
(C) 2015 Society for Endocrinology Printed in Great Britain 
Johnston JD 2004 Photoperiodic regulation of prolactin secretion: changes in intra-pituitary signalling and lactotroph heterogeneity. Journal of Endocrinology 180 351-356. (doi:10.1677/joe.0.1800351)

Johnston JD 2005 Measuring seasonal time within the circadian system: regulation of the suprachiasmatic nuclei by photoperiod. Journal of Neuroendocrinology 17 459-465. (doi:10.1111/j.1365-2826. 2005.01326.x)

Johnston JD, Cagampang FR, Stirland JA, Carr AJ, White MR, Davis JR \& Loudon AS 2003a Evidence for an endogenous per1- and ICERindependent seasonal timer in the hamster pituitary gland. FASEB Journal 17 810-815. (doi:10.1096/fj.02-0837com)

Johnston JD, Messager S, Ebling FJ, Williams LM, Barrett P \& Hazlerigg DG $2003 b$ Gonadotrophin-releasing hormone drives melatonin receptor down-regulation in the developing pituitary gland. PNAS $\mathbf{1 0 0}$ 2831-2835. (doi:10.1073/pnas.0436184100)

Johnston JD, Messager S, Barrett P \& Hazlerigg DG 2003c Melatonin action in the pituitary: neuroendocrine synchronizer and developmental modulator? Journal of Neuroendocrinology 15 405-408. (doi:10.1046/j. 1365-2826.2003.00972.x)

Johnston JD, Bashforth R, Diack A, Andersson H, Lincoln GA \& Hazlerigg DG 2004 Rhythmic melatonin secretion does not correlate with the expression of arylalkylamine $\mathrm{N}$-acetyltransferase, inducible cyclic amp early repressor, period 1 or cryptochrome 1 mRNA in the sheep pineal. Neuroscience 124 789-795. (doi:10.1016/j.neuroscience.2004.01.011)

Johnston JD, Klosen P, Barrett P \& Hazlerigg DG 2006 Regulation of MT melatonin receptor expression in the foetal rat pituitary. Journal of Neuroendocrinology 18 50-56. (doi:10.1111/j.1365-2826.2005.01389.x)

Karamitri A, Renault N, Clement N, Guillaume JL \& Jockers R 2013 Minireview: toward the establishment of a link between melatonin and glucose homeostasis: association of melatonin MT2 receptor variants with type 2 diabetes. Molecular Endocrinology 27 1217-1233. (doi:10.1210/me.2013-1101)

Kemp DM, Ubeda M \& Habener JF 2002 Identification and functional characterization of melatonin Mel 1a receptors in pancreatic $\beta$ cells: potential role in incretin-mediated cell function by sensitization of cAMP signaling. Molecular and Cellular Endocrinology 191 157-166. (doi:10.1016/S0303-7207(02)00064-3)

Klein DC 2007 Arylalkylamine N-acetyltransferase: "the Timezyme". Journal of Biological Chemistry 282 4233-4237. (doi:10.1074/jbc. R600036200)

Klein DC \& Weller JL 1972 Rapid light-induced decrease in pineal serotonin $\mathrm{N}$-acetyltransferase activity. Science 177 532-533. (doi:10.1126/science. 177.4048.532)

Klein D \& Weller JL 1973 Adrenergic-adenosine 3',5'-monophosphate regulation of serotonin $\mathrm{N}$-acetyltransferase activity and the temporal relationship of serotonin $\mathrm{N}$-acetyltransferase activity synthesis of $3 \mathrm{H}-$ $\mathrm{N}$-acetylserotonin and $3 \mathrm{H}$-melatonin in the cultured rat pineal gland. Journal of Pharmacology and Experimental Therapeutics 186 516-527.

Klein DC, Sugden D \& Weller JL 1983 Postsynaptic $\alpha$-adrenergic receptors potentiate the $\beta$-adrenergic stimulation of pineal serotonin $\mathrm{N}$-acetyltransferase. PNAS 80 599-603. (doi:10.1073/pnas.80.2.599)

Klosen P, Bienvenu C, Demarteau O, Dardente H, Guerrero H, Pevet P \& Masson-Pevet M 2002 The mt1 melatonin receptor and ROR $\beta$ receptor are co-localized in specific TSH-immunoreactive cells in the pars tuberalis of the rat pituitary. Journal of Histochemistry and Cytochemistry 50 1647-1657. (doi:10.1177/002215540205001209)

Krauchi K, Cajochen C, Mori D, Graw P \& Wirz-Justice A 1997 Early evening melatonin and S-20098 advance circadian phase and nocturnal regulation of core body temperature. American Journal of Physiology 272 R1178-R1188.

Lafarque M, Oliveros L \& Aguado L 1998 Effect of adenohypophyseal pars tuberalis secretions on pars distalis prolactin liberation. Medicina 58 36-40.

Larsen PJ, Enquist LW \& Card JP 1998 Characterization of the multisynaptic neuronal control of the rat pineal gland using viral transneuronal tracing. European Journal of Neuroscience 10 128-145. (doi:10.1046/j.1460-9568.1998.00003.x)

Lemoine P, Nir T, Laudon M \& Zisapel N 2007 Prolonged-release melatonin improves sleep quality and morning alertness in insomnia patients aged 55 years and older and has no withdrawal effects. Journal of Sleep Research 16 372-380. (doi:10.1111/j.1365-2869.2007.00613.x)

Lerner AB, Case JD, Takahashi Y, Lee TH \& Mori W 1958 Isolation of melatonin, the pineal gland factor that lightens melanocytes. Journal of the American Chemical Society 80 2587. (doi:10.1021/ja01543a060)

Lerner AB, Case JD \& Heinzelman RV 1959 Structure of melatonin. Journal of the American Chemical Society 81 6084-6085. (doi:10.1021/ ja01531a060)

Lewy AJ \& Sack RL 1989 The dim light melatonin onset as a marker for circadian phase position. Chronobiology International 6 93-102. (doi:10.3109/07420528909059144)

Lewy AJ, Tetsuo M, Markey SP, Goodwin FK \& Kopin IJ 1980a Pinealectomy abolishes plasma melatonin in the rat. Journal of Clinical Endocrinology and Metabolism 50 204-205. (doi:10.1210/jcem-50-1-204)

Lewy AJ, Wehr TA, Goodwin FK, Newsome DA \& Markey SP 1980 $b$ Light suppresses melatonin secretion in humans. Science 210 1267-1269. (doi:10.1126/science.7434030)

Lewy AJ, Ahmed S, Jackson JM \& Sack RL 1992 Melatonin shifts human circadian rhythms according to a phase-response curve. Chronobiology International 9 380-392. (doi:10.3109/07420529209064550)

Lincoln GA \& Clarke IJ 1994 Photoperiodically-induced cycles in the secretion of prolactin in hypothalamo-pituitary disconnected rams: evidence for translation of the melatonin signal in the pituitary gland. Journal of Neuroendocrinology 6 251-260. (doi:10.1111/j.1365-2826. 1994.tb00580.x)

Lincoln G, Messager S, Andersson H \& Hazlerigg D 2002 Temporal expression of seven clock genes in the suprachiasmatic nucleus and the pars tuberalis of the sheep: evidence for an internal coincidence timer. PNAS 99 13890-13895. (doi:10.1073/pnas.212517599)

Lincoln GA, Andersson H \& Hazlerigg D 2003 Clock genes and the longterm regulation of prolactin secretion: evidence for a photoperiod/ circannual timer in the pars tuberalis. Journal of Neuroendocrinology 15 390-397. (doi:10.1046/j.1365-2826.2003.00990.x)

Lincoln GA, Johnston JD, Andersson H, Wagner G \& Hazlerigg DG 2005 Photorefractoriness in mammals: dissociating a seasonal timer from the circadian-based photoperiod response. Endocrinology 146 3782-3790. (doi:10.1210/en.2005-0132)

Liu C, Weaver DR, Jin X, Shearman LP, Pieschl RL, Gribkoff VK \& Reppert SM 1997 Molecular dissection of two distinct actions of melatonin on the suprachiasmatic circadian clock. Neuron 19 91-102. (doi:10.1016/S0896-6273(00)80350-5)

Mantele S, Otway DT, Middleton B, Bretschneider S, Wright J, Robertson MD, Skene DJ \& Johnston JD 2012 Daily rhythms of plasma melatonin, but not plasma leptin or leptin mRNA, vary between lean, obese and type 2 diabetic men. PLoS ONE 7 e37123. (doi:10.1371/journal.pone. 0037123)

Martin JE \& Klein DC 1976 Melatonin inhibition of the neonatal pituitary response to luteinizing hormone-releasing factor. Science 191 301-302. (doi:10.1126/science.1108199)

Martin JE \& Sattler C 1979 Developmental loss of the acute inhibitory effect of melatonin on the in vitro pituitary luteinizing hormone and follicle-stimulating hormone responses to luteinizing hormonereleasing hormone. Endocrinology 105 1007-1012. (doi:10.1210/ endo-105-4-1007)

Mason CA, Sparrow N \& Lincoln DW 1977 Structural features of the retinohypothalamic projection in the rat during normal development. Brain Research 132 141-148. (doi:10.1016/0006-8993(77)90711-9)

Maywood ES \& Hastings MH 1995 Lesions of the iodomelatonin-binding sites of the mediobasal hypothalamus spare the lactotropic, but block the gonadotropic response of male Syrian hamsters to short photoperiod and to melatonin. Endocrinology 136 144-153. 
McMullan CJ, Curhan GC, Schernhammer ES \& Forman JP 2013 Association of nocturnal melatonin secretion with insulin resistance in nondiabetic young women. American Journal of Epidemiology $\mathbf{1 7 8}$ 231-238. (doi:10.1093/aje/kws470)

Middleton B, Arendt J \& Stone BM 1997 Complex effects of melatonin on human circadian rhythms in constant dim light. Journal of Biological Rhythms 12 467-477.

Moenter SM, Woodfill CJ \& Karsch FJ 1991 Role of the thyroid gland in seasonal reproduction: thyroidectomy blocks seasonal suppression of reproductive neuroendocrine activity in ewes. Endocrinology $\mathbf{1 2 8}$ 1337-1344. (doi:10.1210/endo-128-3-1337)

Moore RY 1996 Neural control of the pineal gland. Behavioural Brain Research 73 125-130. (doi:10.1016/0166-4328(96)00083-6)

Moore RY \& Eichler VB 1972 Loss of a circadian adrenal corticosterone rhythm following suprachiasmatic lesions in the rat. Brain Research 42 201-206. (doi:10.1016/0006-8993(72)90054-6)

Morgan PJ, Webster CA, Mercer JG, Ross AW, Hazlerigg DG, MacLean A \& Barrett P 1996 The ovine pars tuberalis secretes a factor(s) that regulates gene expression in both lactotropic and nonlactotropic pituitary cells. Endocrinology 137 4018-4026.

Morgan PJ, Ross AW, Graham ES, Adam C, Messager S \& Barrett P 1998 oPer 1 is an early response gene under photoperiodic regulation in the ovine pars tuberalis. Journal of Neuroendocrinology $10319-323$ (doi:10.1046/j.1365-2826.1998.00232.x)

Mundey K, Benloucif S, Harsanyi K, Dubocovich ML \& Zee PC 2005 Phase-dependent treatment of delayed sleep phase syndrome with melatonin. Sleep 28 1271-1278.

Nagtegaal JE, Kerkhof GA, Smits MG, Swart AC \& Van Der Meer YG 1998 Delayed sleep phase syndrome: a placebo-controlled cross-over study on the effects of melatonin administered five hours before the individual dim light melatonin onset. Journal of Sleep Research 7 135-143. (doi:10.1046/j.1365-2869.1998.00102.x)

Nicholls TJ, Follett BK, Goldsmith AR \& Pearson H 1988 Possible homologies between photorefractoriness in sheep and birds: the effect of thyroidectomy on the length of the ewe's breeding season. Reproduction, Nutrition, Development 28 375-385. (doi:10.1051/ rnd:19880304)

Pelisek V \& Vanecek J 2000 Different effects of melatonin pretreatment on cAMP and LH responses of the neonatal rat pituitary cells. Journal of Pineal Research 28 234-241. (doi:10.1034/j.1600-079X.2000.280406.x)

Peschke E 2008 Melatonin, endocrine pancreas and diabetes. Journal of Pineal Research 44 26-40.

Pevet P, Agez L, Bothorel B, Saboureau M, Gauer F, Laurent V \& MassonPevet M 2006 Melatonin in the multi-oscillatory mammalian circadian world. Chronobiology International 23 39-51. (doi:10.1080/ 07420520500482074)

Privat K, Ravault JP, Chesneau D \& Fevre-Montange M 1999 Day/night variation of tryptophan hydroxylase and serotonin N-acetyltransferase mRNA levels in the ovine pineal gland and retina. Journal of Pineal Research 26 193-203. (doi:10.1111/j.1600-079X.1999.tb00584.x)

Rajaratnam SM, Dijk DJ, Middleton B, Stone BM \& Arendt J 2003 Melatonin phase-shifts human circadian rhythms with no evidence of changes in the duration of endogenous melatonin secretion or the 24-hour production of reproductive hormones. Journal of Clinical Endocrinology and Metabolism 88 4303-4309. (doi:10.1210/jc.2003-030460)

Reiter RJ 1993 The melatonin rhythm: both a clock and a calendar. Experientia 49 654-664. (doi:10.1007/BF01923947)

Reppert SM 1997 Melatonin receptors: molecular biology of a new family of G protein-coupled receptors. Journal of Biological Rhythms 12 528-531. (doi:10.1177/074873049701200606)

Reppert SM \& Klein DC 1978 Transport of maternal[3H]melatonin to suckling rats and the fate of $[3 \mathrm{H}]$ melatonin in the neonatal rat. Endocrinology 102 582-588. (doi:10.1210/endo-102-2-582)

Reppert SM \& Weaver DR 1995 Melatonin madness. Cell 83 1059-1062. (doi:10.1016/0092-8674(95)90131-0)
Reppert SM, Chez RA, Anderson A \& Klein DC 1979 Maternal-fetal transfer of melatonin in the non-human primate. Pediatric Research 13 788-791. (doi:10.1203/00006450-197906000-00015)

Reppert SM, Weaver DR \& Ebisawa T 1994 Cloning and characterization of a mammalian melatonin receptor that mediates reproductive and circadian responses. Neuron 13 1177-1185. (doi:10.1016/08966273(94)90055-8)

Reppert SM, Godson C, Mahle CD, Weaver DR, Slaugenhaupt SA \& Gusella JF 1995a Molecular characterization of a second melatonin receptor expressed in human retina and brain: the Mel1b melatonin receptor. PNAS 92 8734-8738. (doi:10.1073/pnas.92.19.8734)

Reppert SM, Weaver DR, Cassone VM, Godson C \& Kolakowski LF Jr $1995 b$ Melatonin receptors are for the birds: molecular analysis of two receptor subtypes differentially expressed in chick brain. Neuron 15 1003-1015. (doi:10.1016/0896-6273(95)90090-X)

Revel FG, Saboureau M, Pevet P, Mikkelsen JD \& Simonneaux V 2006 Melatonin regulates type 2 deiodinase gene expression in the Syrian hamster. Endocrinology 147 4680-4687. (doi:10.1210/en.2006-0606)

Revell VL \& Eastman CI 2005 How to trick mother nature into letting you fly around or stay up all night. Journal of Biological Rhythms $20353-365$. (doi:10.1177/0748730405277233)

Rivkees SA \& Reppert SM 1991 Appearance of melatonin receptors during embryonic life in Siberian hamsters (Phodopus sungorous). Brain Research 568 345-349. (doi:10.1016/0006-8993(91)91424-Y)

Schomerus C, Korf HW, Laedtke E, Weller JL \& Klein DC 2000 Selective adrenergic/cyclic AMP-dependent switch-off of proteasomal proteolysis alone switches on neural signal transduction: an example from the pineal gland. Journal of Neurochemistry 75 2123-2132. (doi:10.1046/j. 1471-4159.2000.0752123.x)

Scully KM \& Rosenfeld MG 2002 Pituitary development: regulatory codes in mammalian organogenesis. Science 295 2231-2235. (doi:10.1126/ science.1062736)

Seron-Ferre M, Mendez N, Abarzua-Catalan L, Vilches N, Valenzuela FJ, Reynolds HE, Llanos AJ, Rojas A, Valenzuela GJ \& Torres-Farfan C 2012 Circadian rhythms in the fetus. Molecular and Cellular Endocrinology 349 68-75. (doi:10.1016/j.mce.2011.07.039)

Seron-Ferre M, Reynolds H, Mendez NA, Mondaca M, Valenzuela F, Ebensperger R, Valenzuela GJ, Herrera EA, Llanos AJ \& Torres-Farfan C 2014 Impact of maternal melatonin suppression on amount and functionality of brown adipose tissue (BAT) in the newborn sheep. Frontiers in Endocrinology 5232.

Skene DJ \& Arendt J 2006 Human circadian rhythms: physiological and therapeutic relevance of light and melatonin. Annals of Clinical Biochemistry 43 344-353. (doi:10.1258/000456306778520142)

Skene DJ \& Arendt J 2007 Circadian rhythm sleep disorders in the blind and their treatment with melatonin. Sleep Medicine 8 651-655. (doi:10. 1016/j.sleep.2006.11.013)

Stanfield B \& Cowan WM 1976 Evidence for a change in the retinohypothalamic projection in the rat following early removal of one eye. Brain Research 104 129-136. (doi:10.1016/0006-8993(76)90652-1)

Stehle JH, von Gall C, Schomerus C \& Korf HW 2001 Of rodents and ungulates and melatonin: creating a uniform code for darkness by different signaling mechanisms. Journal of Biological Rhythms 16 312-325. (doi:10.1177/074873001129002033)

Stehle JH, von Gall C \& Korf HW 2003 Melatonin: a clock-output, a clockinput. Journal of Neuroendocrinology 15 383-389. (doi:10.1046/j.13652826.2003.01001.x)

Stephan FK \& Zucker I 1972 Circadian rhythms in drinking behavior and locomotor activity of rats are eliminated by hypothalamic lesions. PNAS 69 1583-1586. (doi:10.1073/pnas.69.6.1583)

Stevenson TJ \& Prendergast BJ 2015 Photoperiodic time measurement and seasonal immunological plasticity. Frontiers in Neuroendocrinology $\mathbf{3 7}$ 76-88. (doi:10.1016/j.yfrne.2014.10.002)

Stirland JA, Johnston JD, Cagampang FR, Morgan PJ, Castro MG, White MR, Davis JR \& Loudon AS 2001 Photoperiodic regulation of prolactin gene expression in the Syrian hamster by a pars tuberalis-derived factor. 
Journal of Neuroendocrinology 13 147-157. (doi:10.1046/j.1365-2826. 2001.00611.x)

Sun ZS, Albrecht U, Zhuchenko O, Bailey J, Eichele G \& Lee CC 1997 RIGUI, a putative mammalian ortholog of the Drosophila period gene. Cell 90 1003-1011. (doi:10.1016/S0092-8674(00)80366-9)

Tamarkin L, Westrom WK, Hamill AI \& Goldman BD 1976 Effect of melatonin on the reproductive systems of male and female Syrian hamsters: a diurnal rhythm in sensitivity to melatonin. Endocrinology 99 1534-1541. (doi:10.1210/endo-99-6-1534)

Tamarkin L, Lefebvre NG, Hollister CW \& Goldman BD 1977 Effect of melatonin administered during the night on reproductive function in the Syrian hamster. Endocrinology 101 631-634. (doi:10.1210/endo101-2-631)

Teclemariam-Mesbah R, Ter Horst GJ, Postema F, Wortel J \& Buijs RM 1999 Anatomical demonstration of the suprachiasmatic nucleus-pineal pathway. Journal of Comparative Neurology 406 171-182. (doi:10.1002/ (SICI)1096-9861(19990405)406:2\%3C;171::AID-CNE3\%3E;3.0.CO;2-U)

Thomas JM \& Hoffman BB 1987 Adenylate cyclase supersensitivity: a general means of cellular adaptation to inhibitory agonists? Trends in Pharmacological Sciences 8 308-311. (doi:10.1016/0165-6147(87)90124-6)

Torres-Farfan C, Mendez N, Abarzua-Catalan L, Vilches N, Valenzuela GJ \& Seron-Ferre M 2011 A circadian clock entrained by melatonin is ticking in the rat fetal adrenal. Endocrinology 152 1891-1900. (doi:10.1210/en. 2010-1260)

Tremblay JJ \& Drouin J 1999 Egr-1 is a downstream effector of GnRH and synergizes by direct interaction with Ptx1 and SF-1 to enhance luteinizing hormone $\beta$ gene transcription. Molecular and Cellular Biology 19 2567-2576.

Turek FW \& Gillette MU 2004 Melatonin, sleep, and circadian rhythms: rationale for development of specific melatonin agonists. Sleep Medicine 5 523-532. (doi:10.1016/j.sleep.2004.07.009)

Unfried C, Burbach G, Korf HW \& von Gall C 2010 Melatonin receptor 1-dependent gene expression in the mouse pars tuberalis as revealed by cDNA microarray analysis and in situ hybridization. Journal of Pineal Research 48 148-156. (doi:10.1111/j.1600-079X.2009.00738.x)

Vanecek J 1988a Melatonin binding sites. Journal of Neurochemistry $\mathbf{5 1}$ 1436-1440. (doi:10.1111/j.1471-4159.1988.tb01108.x)

Vanecek J $1988 b$ The melatonin receptors in rat ontogenesis. Neuroendocrinology 48 201-203. (doi:10.1159/000125008)

Vanecek J 1999 Inhibitory effect of melatonin on GnRH-induced LH release. Reviews of Reproduction 4 67-72. (doi:10.1530/ror.0.0040067)

Vanecek J, Sugden D, Weller J \& Klein DC 1985 Atypical synergistic $\alpha$ 1- and $\beta$-adrenergic regulation of adenosine $3^{\prime}, 5^{\prime}$-monophosphate and guanosine $3^{\prime}, 5^{\prime}$-monophosphate in rat pinealocytes. Endocrinology 116 2167-2173. (doi:10.1210/endo-116-6-2167)

Vriend J 1985 Effects of melatonin and thyroxine replacement on thyrotropin, luteinizing hormone, and prolactin in male hypothyroid hamsters. Endocrinology 117 2402-2407. (doi:10.1210/ endo-117-6-2402)
Warman VL, Dijk DJ, Warman GR, Arendt J \& Skene DJ 2003 Phase advancing human circadian rhythms with short wavelength light. Neuroscience Letters 342 37-40. (doi:10.1016/S0304-3940(03)00223-4)

Weaver DR \& Reppert SM 1990 Melatonin receptors are present in the ferret pars tuberalis and pars distalis, but not in brain. Endocrinology 127 2607-2609. (doi:10.1210/endo-127-5-2607)

Webster JR, Moenter SM, Woodfill CJ \& Karsch FJ 1991 Role of the thyroid gland in seasonal reproduction. II. Thyroxine allows a season-specific suppression of gonadotropin secretion in sheep. Endocrinology 129 176-183. (doi:10.1210/endo-129-1-176)

Witt-Enderby PA, Masana MI \& Dubocovich ML 1998 Physiological exposure to melatonin supersensitizes the cyclic adenosine $3^{\prime}, 5^{\prime}$-monophosphate-dependent signal transduction cascade in Chinese hamster ovary cells expressing the human mt1 melatonin receptor. Endocrinology 139 3064-3071.

Wittkowski W, Bockmann J, Kreutz MR \& Bockers TM 1999 Cell and molecular biology of the pars tuberalis of the pituitary. International Review of Cytology 185 157-194.

Wood S \& Loudon A 2014 Clocks for all seasons: unwinding the roles and mechanisms of circadian and interval timers in the hypothalamus and pituitary. Journal of Endocrinology 222 R39-R59. (doi:10.1530/JOE14-0141)

Yasuo S, Watanabe M, Nakao N, Takagi T, Follett BK, Ebihara S \& Yoshimura T 2005 The reciprocal switching of two thyroid hormoneactivating and -inactivating enzyme genes is involved in the photoperiodic gonadal response of Japanese quail. Endocrinology 146 2551-2554. (doi:10.1210/en.2005-0057)

Yellon SM \& Longo LD 1987 Melatonin rhythms in fetal and maternal circulation during pregnancy in sheep. American Journal of Physiology 252 E799-E802.

Yoshimura T 2013 Thyroid hormone and seasonal regulation of reproduction. Frontiers in Neuroendocrinology 34 157-166. (doi:10.1016/ j.yfrne.2013.04.002)

Yoshimura T, Yasuo S, Watanabe M, Iigo M, Yamamura T, Hirunagi K \& Ebihara S 2003 Light-induced hormone conversion of $\mathrm{T}_{4}$ to $\mathrm{T}_{3}$ regulates photoperiodic response of gonads in birds. Nature $\mathbf{4 2 6}$ 178-181. (doi:10.1038/nature02117)

Zawilska JB, Skene DJ \& Arendt J 2009 Physiology and pharmacology of melatonin in relation to biological rhythms. Pharmacological Reports 61 383-410. (doi:10.1016/S1734-1140(09)70081-7)

Zemdegs IZ, McMillen IC, Walker DW, Thorburn GD \& Nowak R 1988 Diurnal rhythms in plasma melatonin concentrations in the fetal sheep and pregnant ewe during late gestation. Endocrinology 123 284-289. (doi:10.1210/endo-123-1-284)

Zhdanova Wurtm IV, an RJ, Morabito C, Piotrovska VR \& Lynch HJ 1996 Effects of low oral doses of melatonin, given 2-4 hours before habitual bedtime, on sleep in normal young humans. Sleep 19 423-431.

Received in final form 29 May 2015

Accepted 17 June 2015

Accepted Preprint published online 22 June 2015 http://joe.endocrinology-journals.org

DOI: 10.1530/JOE-15-0119
(C) 2015 Society for Endocrinology Printed in Great Britain
Published by Bioscientifica Ltd 